\title{
Depopulacija i starenje u Istočnoj Hrvatskoj
}

\author{
DrAŽEN ŽIVIĆ* \\ • https://doi.org/10.31823/d.26.4.6 • \\ UDK: 314.116-026.24(497.54) • Prethodno priopćenje \\ Primljeno: 25. siječnja 2018. • Prihvaćeno: 6. prosinca 2018.
}

* Dr. sc. Dražen Živić, Institut društvenih znanosti Ivo Pilar - Područni centar Vukovar, J. J. Strossmayera 25, p. p. 58, 32000 Vukovar, drazen.zivic@pilar.hr

Sažetak: Predmet istraživanja u ovom radu jest ukupno kretanje stanovništva i suvremene promjene u biološkoj strukturi stanovništva Istočne Hrvatske. Svrha istraživanja jest na temelju rezultata dvaju posljednjih popisa stanovništva (2001.i 2011.), analize vitalne statistike za razdoblje 2001. - 2016. te projekcija budućega kretanja stanovništva (do 2030., odnosno 2051.) utvrditi, analizirati i interpretirati osnovne agregatne pokazatelje koji indiciraju trendove u općem, prirodnom i mehaničkom kretanju stanovništva Istočne Hrvatske te njihovu interakcijsku povezanost uz proces demografskoga starenja. Cilj je rada utvrditi i opisati dosegnutu razinu ukupne depopulacije i demografskoga starenja Istočne Hrvatske. S obzirom na to da se opći i parcijalni procesi depopulacije nalaze u snažnom korelativnom odnosu spram oblikovanja biološke strukture stanovništva, jasno je da oni zajedno čine dalekosežne regresivne čimbenike populacijskoga, a time i društveno-gospodarskoga razvoja Istočne Hrvatske. Ako se nastave dosadašnji nepovoljni demografski trendovi, osobito u bioreprodukciji, realno se može očekivati da će Istočna Hrvatska do sredine 21. stoljeća prirodnim $i$ mehaničkim putem izgubiti trećinu stanovništva popisanoga 2011. godine. Očekivani daljnji pad broja stanovnika ne će biti linearan, nego se očekuje jačanje debalansa u odnosu izmedu pojedinih velikih (funkcionalnih) dobnih kontingenata, osobito u odnosu: mlado - staro stanovništvo.

Ključne riječi: Istočna Hrvatska, demografski razvoj, depopulacija, demografsko starenje. 


\section{Uvodne i metodološke napomene}

Predmet istraživanja u ovom radu jest ukupno kretanje stanovništva ${ }^{1}$ i promjene $u$ biološkoj (demografskoj) strukturi (prema spolu i dobi) stanovništva Istočne Hrvatske $^{2}$ u međupopisnom razdoblju 2001. - 2011. godine. Znanstvena relevantnost provedene demografske analize proizlazi iz dvaju bitnih, pa i nezaobilaznih ishodišta: (1) poznavanje i razumijevanje prošlih i trenutačnih procesa i trendova u razvoju neke populacije neophodno je radi pravilnoga vrjednovanja povezanosti zakonitosti demografskoga, društvenoga i ekonomskoga razvoja nekoga prostora te predviđanja (prognoza) budućih demografskih trendova i odnosa; (2) Istočna Hrvatska, prema formalnim statističkim demografskim indikatorima nalazi se u jakom demografskom pražnjenju što implicira niz dugoročnih i vrlo negativnih demografskih, socijalnih i ekonomskih posljedica, što pak sa svoje strane ne će pridonijeti skoroj i sveobuhvatnoj revitalizaciji toga prostora i s populacijskoga is ekonomskoga motrišta.

Svrha je istraživanja na temelju rezultata dvaju posljednjih popisa stanovništva (2001. i 2011.) i analize vremenski usporedive serije podataka vitalne statistike za razdoblje 2001. - 2016., kao i projekcija budućega kretanja stanovništva (do 2030., odnosno 2051.), utvrditi, analizirati i interpretirati osnovne agregatne pokazatelje koji indiciraju trendove u općem, prirodnom i mehaničkom kretanju stanovništva Istočne Hrvatske te njihovu dinamičku interakcijsku povezanost uz proces starenja stanovništva. Takav je pristup, prema A. Wertheimer-Baletić, > opravdan iz sljedećih razloga: (1) starosna je struktura izravno određena sastavnicama prirodnoga kretanja stanovništva, (2) između prirodnih sastavnica (nataliteta, mortaliteta) i starosne strukture postoji izravna i stalna transparentna interakcija, i (3) određena brojčana razina prirodnih sastavnica sadrži i utjecaj sastavnica migracije (imigracije, emigracije), kao i utjecaj drugih značajnih struktura i eksternih čimbenika razvoja stanovništva «. ${ }^{3}$

\footnotetext{
${ }^{1}$ Ukupno kretanje stanovništva čine dvije dinamičke sastavnice: prirodno (natalitet, mortalitet) i mehaničko kretanje (emigracija, imigracija). Najjednostavniji agregatni izraz ukupnoga kretanja stanovništva jest (međupopisna) promjena broja stanovnika. Ovisno o međuodnosu prirodnoga i mehaničkoga kretanja, pri čemu natalitet i imigracija čine aktivu, a mortalitet i emigracija pasivu demografske bilance, međupopisna promjena broja stanovnika može biti pozitivna (demografski porast/ekspanzija), negativna (demografski pad/regres/depopulacija) ili stagnantna.

${ }^{2} \mathrm{U}$ administrativnom smislu prostorni obuhvat Istočne Hrvatske u ovom radu uključuje: Brodskoposavsku, Osječko-baranjsku, Požeško-slavonsku, Virovitičko-podravsku i Vukovarsko-srijemsku županiju. Predmetne županije u svojem administrativnom okviru uključuju ukupno 22 grada i 105 općina te 997 samostalnih naselja, a prostiru se na ukupno 12486 četvornih kilometara, što je 22,1\% ukupne kopnene površine Republike Hrvatske.

${ }^{3}$ A. WERTHEIMER-BALETIĆ, Depopulacija i starenje stanovništva - temeljni demografski procesi u Hrvatskoj, u: Društvena istraživanja 13(2004.)4-5, 633.
} 
Suvremeni trendovi i odnosi u općem, prirodnom i mehaničkom kretanju stanovništva, kao i oblikovanju biološke strukture (spol i dob), dugoročni su izraz demografskih trendova u prošlosti, ali su isto tako relevantni za odvijanje i razumijevanje budućega kretanja i razvoja stanovništva Istočne Hrvatske. Cilj je rada stoga utvrditi i opisati dosegnutu razinu ukupne depopulacije i demografskoga starenja istočnohrvatskih županija kroz predmetno razdoblje. Treba napomenuti da je ovaj rad svojevrsni nastavak (produbljenje) već objavljenih analiza ${ }^{4}$ u kojima je tematizirana suvremena demografska problematika Istočne Hrvatske te da, uvodeći u analizu novije podatke, prije svega, vitalne statistike, pridonosi potpunijem poznavanju korelacijske povezanosti dinamičkih i strukturnih procesa, odnosa, struktura i pojava u predmetnom prostoru.

Provedena demografska analiza oslanja se na objavljene rezultate popisa stanovniš-

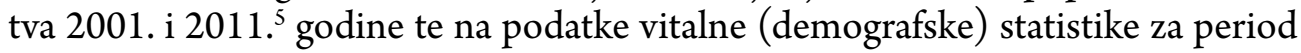
2001. - 2016. godine. ${ }^{6}$ Potrebno je na ovom mjestu upozoriti da su popisi stanovništva iz 2001. i2011. godine, premda oba počivaju na konceptu uobičajenoga mjesta stanovanja, provedeni prema izmijenjenoj metodologiji što otežava međupopisnu usporedbu njihovih rezultata. ${ }^{7}$ Navedeno utječe na pouzdanost izračunanih indikatora demografske analize, ali nas ne sprječava u donošenju valjanih zaključaka o intenzitetu i smjeru kretanja i razvoja stanovništva Istočne Hrvatske u analiziranom međupopisnom razdoblju.

${ }^{4}$ Usp. D. ŽIVIĆ, Demografski okvir društvene stabilnosti i gospodarskog razvoja Istočne Hrvatske (2001. - 2011.), u: Uloga obrazovanja u identitetu društva i ekonomiji znanja. Zbornik radova, Osijek, 2013., 65-87.; D. ŽIVIĆ, Suvremena migracija kao odrednica depopulacije istočne Hrvatske (2001. - 2014.), u: Sociokulturno nasljede i gospodarski razvoj. Zbornik radova sa znanstvenoga skupa globalizacija i regionalni identitet, Osijek, 2016., 52-75.; D. ŽIVIĆ, I. ŽEBEC ŠILJ, S. CVIKIĆ, Demografski i ekonomski kontekst razvojnog zaostajanja Istočne Hrvatske, u: Slavonija - hrvatska i europska regija, Zagreb, 2016., 129-159.; D. ŽIVIĆ, Demografsko pražnjenje Istočne Hrvatske, u: Političke analize 7(2017.)31, 24-32.

${ }^{5}$ Popisi stanovništva 2001. i 2011., DZSRH, Zagreb (www.dzs.hr).

${ }^{6}$ Priopćenja o prirodnom kretanju stanovništva Hrvatske, Vitalna statistika, DZSRH, Zagreb (www. dzs.hr).

${ }^{7}$ Predviđeni opseg ovoga rada ne dopušta pojašnjenje metodoloških aspekata međupopisne (ne) usporedivosti rezultata popisa 2001. i 2011. (kao i u odnosu na ranije popisne godine). Stoga za detaljniji uvid u metodološku popisnu problematiku upućujem na: A. AKRAP, Promjene broja i prostornoga razmještaja stanovništva Hrvatske i županija 1961. - 2011., u: V. PULJIZ, J. TICA i D. VIDOVIĆ (ur.), Migracije i razvoj Hrvatske. Podloga za hrvatsku migracijsku strategiju, Zagreb, 2014., 25-71. 


\section{1. Čimbenici demografskoga razvoja Istočne hrvatske}

Istočna Hrvatska (nešto više od petine teritorija i oko petine ukupnoga stanovništva Hrvatske) jest hrvatska makroregija koja prema formalnim statističkim demografskim pokazateljima i kriterijima ima u odnosu na druge hrvatske makroregije najnepovoljnija dinamička demografska obilježja. ${ }^{8}$ Riječ je o prostoru koji je u manje od pola stoljeća od obećane zemlje s brojnom imigracijom (dvije agrarne kolonizacije i imigracija radne snage, uglavnom iz Bosne i Hercegovine) i mladim, vitalnim stanovništvom postao jakim žarištem depopulacije, iseljavanja i ostarjelosti populacije. ${ }^{9} \mathrm{U}$ tom kontekstu A. Akrap podsjeća da su $\gg$ do sredine XX. stoljeća završile /su/ agrarne kolonizacije kao dominantan činitelj u preraspodjeli stanovništva između siromašnih agrarno prenapučenih i plodnom zemljom bogatih hrvatskih područja (...). Kolonizacijska su područja gospodarski napredovala dok je osnovni izvor egzistencije bila poljoprivreda. Postupnom dominacijom izvan poljoprivrednog sektora nekad bogata Slavonija postaje naglašeno emigracijska «. ${ }^{10}$

Suvremenu demografsku sliku Istočne Hrvatske karakteriziraju dakle negativni demografski trendovi i procesi koji imaju dominantno depopulacijska obilježja. U tom smislu Istočna Hrvatska prati opći smjer/trend demografskih promjena u Hrvatskoj, u kojoj su ukupna depopulacija i demografsko starenje temeljni i najvažniji opći reprodukcijski i strukturno-demografski procesi. ${ }^{11} \mathrm{Uz}$ ukupnu i prirodnu depopulaciju, tj. međupopisno smanjenje broja stanovnika i veće umiranje od rađanja, na današnje demografsko stanje Istočne Hrvatske bitno utječe mehaničko kretanje stanovništva, odnosno brojnije iseljavanje od doseljavanja koje, među ostalim, indicira i negativna gruba migracijska bilanca.

Današnje demografsko stanje posljedica je dugoročnoga djelovanja brojnih općih, ali i specifičnih endogenih i egzogenih/eksternih čimbenika koji su (pre)često remetili normalan razvoj stanovništva, pa ih stoga najčešće i nazivamo destabilizacijskima. Oni su doveli Istočnu Hrvatsku krajem 20. i početkom 21. stoljeća na prag potpunoga demografskoga sloma jer njezini demoreproduktivni potencijali, zahvaljujući pojačanom iseljavanju u posljednjih nekoliko godina te ubrzanom starenju, postaju sve uži i skromniji.

${ }^{8}$ D. ŽIVIĆ, Demografsko pražnjenje Istočne Hrvatske, 24-32.

${ }^{9}$ Detaljnije vidjeti u: A. WERTHEIMER-BALETIĆ, Demografski razvoj Slavonije i Baranje, u: Treći znanstveni sabor Slavonije i Baranje, I, Osijek, 1983., 90-104.; D. ŽIVIĆ, Promjene u dinamici stanovništva Istočne Hrvatske 1948-1991., u: Geografski glasnik 57(1995.), 71-92.; D. ŽIVIĆ, Demografsko pražnjenje Istočne Hrvatske, 24-32.

${ }^{10}$ A. AKRAP, Demografski slom Hrvatske: Hrvatska do 2051., u: Bogoslovska smotra 85(2015.)3, 855-868., ovdje 857.

${ }^{11}$ Detaljnije vidjeti u: A. WERTHEIMER-BALETIĆ, Depopulacija i starenje stanovništva - temeljni demografski procesi u Hrvatskoj, 631-651. 
Među dugoročne demografske, ali i gospodarske, socijalne, političke i druge odrednice sve nepovoljnije demografske slike Istočne Hrvatske (osobito u kontekstu smanjivanja nataliteta) svakako treba ubrojiti:

- dva svjetska rata i Domovinski rat (visoki izravni i napose migracijski gubitci)

- česte i brojne europske i prekomorske iseljeničke struje, neke s izrazitim političkim, a neke s naglašenim ekonomskim motivacijskim obilježjima

- tradicionalni denatalitetni trend u reprodukciji ili bijelu kugu

- procese modernizacije (industrijalizacija, deagrarizacija, deruralizacija, urbanizacija) koji su, zbog stihijnosti procesa i neorganiziranosti sustava, uz pozitivne, imali i brojne negativne učinke (besperspektivnost poljoprivrede, osiromašivanje stanovništva, dugoročno nepovoljna politika prema selu i izrazito jak ruralni egzodus)

- zaostajanje u regionalnom razvoju zbog rušilačkih učinaka rata i složenih posljedica tranzicijske deindustrijalizacije 1990-ih godina što je utjecalo na jačanje svojevrsne razvojne i demografske perifernosti ${ }^{12}$

- promjene u hijerarhiji i strukturi društvenih vrijednosti, osobito u odnosu na brak, obitelj i djecu

- povećanje razine obrazovanosti žena, povećanje razine zaposlenosti žena izvan kuće, širenje zdravstvene zaštite, mijenjanje uvjeta rada i života obitelji u gradu u odnosu na ruralne sredine $\mathrm{e}^{13}$

- izostanak pravovremenoga, cjelovitoga i sustavnoga odgovora nacionalnih, pa i lokalnih struktura na izazove koji su Istočnu Hrvatsku pogurnuli u zagrljaj depopulacije.

Stoga je iz naprijed navedenih razloga razumljivo, pa i očekivano, promatrano s ekonomskoga i regionalnoga motrišta, razvojno zaostajanje Istočne Hrvatske, osobito u posljednjih dvadesetak godina. Potonje potvrđuju relevantni sintetički pokazatelji regionalnoga i ekonomskoga razvoja koji su uglavnom daleko ispod hrvatskoga prosjeka te impliciraju zaključak da je Istočna Hrvatska najslabije razvijena hrvatska makroregija. ${ }^{14}$ Naime svih pet istočnohrvatskih županija spadaju u red županija $\mathrm{s}$ najnižim vrijednostima BDP-a, kao is najsporijim trendom njegova rasta u posljed-

${ }^{12}$ M. MATIŠIĆ, D. PEJNOVIĆ, Uzroci i posljedice zaostajanja Istočne Hrvatske u regionalnom razvoju Hrvatske, u: Hrvatski geografski glasnik 77(2015.)2, 101-140.

${ }^{13}$ A. WERTHEIMER-BALETIĆ, Depopulacija i starenje stanovništva - temeljni demografski procesi u Hrvatskoj, 631-651.

${ }^{14}$ M. MATIŠIĆ, D. PEJNOVIĆ, Uzroci i posljedice zaostajanja Istočne Hrvatske u regionalnom razvoju Hrvatske, 101-140. 
njih desetak godina. ${ }^{15}$ Osim toga svih pet istočnohrvatskih županija ulazi u skupinu potpomognutih područja u kojima je indeks razvijenosti 2010. i 2013. godine bio manji od $75 \%$ prosjeka Republike Hrvatske, s tim da se samo Grad Osijek nalazio u skupini čiji je indeks razvijenosti bio između $100 \%$ i $125 \%$ prosjeka Republike Hrvatske. ${ }^{16} \mathrm{U}$ tom kontekstu A. Šundalić ističe da je regionalna nerazvijenost istočnohrvatskoga prostora prije svega posljedica rata, zapostavljenosti poljoprivrede, loše privatizacije, lošega političkoga i gospodarskoga menadžmenta i neadekvatne političke koncepcije gospodarenja resursima te da bi današnje rasprave o siromaštvu i zaostajanju toga dijela Hrvatske trebalo »shvaćati u prvom redu kao rasprave o dva procesa: 1. o zapostavljanju i neprofitabilnosti do jučer dominirajuće djelatnosti - poljoprivrede, ali i 2 . o depopulaciji sela koje je dominiralo vitalnošću i tradicijom agrarne orijentacije $\ll .{ }^{17}$ Drugim riječima, depopulacijski kontekst u kojem se danas (a predvidivo i u budućnosti) nalazi Istočna Hrvatska ne će i ne može biti povoljan okvir za njezinu punu gospodarsku, društvenu i populacijsku revitalizaciju, osobito ako i dalje budu izostajale snažnije i sustavnije društvene i ekonomske intervencije s nacionalne razine.

Krizna obilježja socioekonomskoga razvoja (jaka deindustrijalizacija) snažan su push faktor demografskoga pražnjenja i u kontekstu sve nepovoljnije bioreprodukcije i u smislu sve snažnijega iseljavanja, napose u inozemstvo, što je posebno došlo do izražaja posljednjih nekoliko godina, bez jasnijega znaka koji bi ukazivao na zaustavljanje ili barem zamjetnije usporavanje brojčano jake (i neselektivne) emigracije. ${ }^{18}$

\section{Ukupno kretanje stanovništva}

\subsection{Promjena broja Stanovnika - UKupNa depopulacija}

Komparativna analiza rezultata popisa stanovništva 2001. i 2011. godine i na razini ukupnoga službenoga broja stanovnika i na razini stanovništva $u$ zemlji ${ }^{19}$ upućuje na ukupnu depopulaciju ili opadajuću opću reprodukciju stanovništva u širem smislu riječi kao opći demografski dinamički proces/trend u kretanju stanovništva Istočne Hrvatske. Potrebno je odmah upozoriti da je depopulacija uvijek rezultanta kumulativnoga i dugoročnoga učinka više odrednica demografskoga razvoja te da

\footnotetext{
${ }^{15}$ Detaljnije vidjeti u: D. ŽIVIĆ, I. ŽEBEC ŠILJ, S. CVIKIĆ, Demografski i ekonomski kontekst razvojnog zaostajanja Istočne Hrvatske, 129-159.

${ }^{16}$ Analitička podloga za izradu Strategije regionalnog razvoja Republike Hrvatske, Zagreb: Ekonomski institut, 2015.

${ }^{17}$ A. ŠUNDALIĆ, Osiromašivanje i nerazvijenost - Slavonija i Baranja u očima njezinih stanovnika, u: Socijalna ekologija 15(2006.)1-2, 141.

${ }^{18}$ D. ŽIVIĆ, Suvremena migracija kao odrednica depopulacije istočne Hrvatske (2001. - 2014.), 52-75.

${ }^{19}$ Usp. A. AKRAP, Promjene broja i prostornog razmještaja stanovništva Hrvatske i županija 1961. 2011., 25-71.
} 
ima brojne izravne i neizravne posljedice i po buduću demografsku dinamiku i po razvoj struktura stanovništva, osobito onih koje su važne za bioreprodukciju i ekonomsku aktivnost neke populacije.

Iz podataka i izračunanih pokazatelja u analitičkim tablicama 1 i 2 razvidno je da je promjena broja stanovnika Istočne Hrvatske između 2001. i 2011. bila negativna, što ukazuje na opadajuću opću reprodukciju stanovništva, tj. na ukupnu depopulaciju ili demografski regres. Ukupan službeni broj stanovnika u posljednjem je medupopisnom razdoblju smanjen za 9,6\% (apsolutno za 85261 osobu), dok je broj stanovnika $u$ zemlji smanjen za 3,3 \% (apsolutno za 27502 osobe). Prosječna relativna godišnja stopa međupopisne promjene ukupnoga službenoga broja stanovnika u posljednjem međupopisju iznosila je $-1,0 \%$, a stanovništva u zemlji $-0,3 \%$.

Tablica 1. Promjena ukupnoga (službenoga) broja stanovnika Istočne Hrvatske po županijama između 2001. i 2011. godine

\begin{tabular}{|l|c|c|c|c|}
\hline \multirow{2}{*}{\multicolumn{1}{|c|}{ Županija }} & \multicolumn{2}{|c|}{ Broj stanovnika } & \multirow{2}{*}{$\begin{array}{c}\text { Apsolutna } \\
\text { promjena }\end{array}$} & $\begin{array}{c}\text { Indeks } \\
\text { međupopisne } \\
\text { promjene }\end{array}$ \\
\cline { 2 - 5 } & $\mathbf{2 0 0 1 .}$ & $\mathbf{2 0 1 1 .}$ & -18190 & 89,7 \\
\hline Brodsko-posavska & 176765 & 158575 & -190 & 92,3 \\
\hline Osječko-baranjska & 330506 & 305032 & -25474 & 90,9 \\
\hline Požeško-slavonska & 85831 & 78034 & -7797 & 90,8 \\
\hline Virovitičko-podravska & 93389 & 84836 & -8553 & 87,8 \\
\hline Vukovarsko-srijemska & 204768 & 179521 & -25247 & 90,4 \\
\hline Istočna Hrvatska & 891259 & 805998 & -85261 & \\
\hline
\end{tabular}

IZVOR: Popisi stanovništva 2001. i 2011., DZSRH, Zagreb (www.dzs.hr); A. AKRAP, Promjene broja i prostornog razmještaja stanovništva Hrvatske i županija 1961. - 2011., u: V. PULJIZ, J. TICA i D. VIDOVIĆ (ur.), Migracije i razvoj Hrvatske. Podloga za hrvatsku migracijsku strategiju, Zagreb, 2014., 34-35.

Sve županije Istočne Hrvatske u analiziranom međupopisju zabilježile su demografski regres, koji je, evolucijski gledano, zapravo, nastavak sve nepovoljnijih procesa započetih još prije Domovinskoga rata (premda se oni tada $u$ formalnom statističkom smislu još uvijek nisu odrazili na međupopisno smanjenje broja stanovnika), a koji su osobito intenzivni bili 1990-ih godina zbog rata i visokih izravnih i migracijskih demografskih ratnih gubitaka. Naime, prema dosadašnjim istraživanjima, koja su se temeljila na dostupnim izvorima, izravni demografski gubitci (poginuli, umrli zbog posljedica rata i nestali) u pet istočnohrvatskih županija procijenjeni su na ukupno 10615 osoba, od kojih 367 ili 3,5 \% iz Virovitičko-podravske, 782 ili 7, 7\% iz Požeš- 
ko-slavonske, 1089 ili 10, 7\% iz Brodsko-posavske, 2116 ili 20,8 \% iz Osječko-baranjske i - najviše - 5811 osoba ili 57,2\% iz Vukovarsko-srijemske županije. Ujedno približno 185000 stanovnika Istočne Hrvatske bilo je prognano iz svojih domova, mnogi su umrli u progonstvu, iselili u druge zemlje ili se iz drugih razloga nisu vratili u svoja naselja prijeratnoga prebivališta/boravišta. Također oko 55000 stanovnika Istočne Hrvatske pretežno srpske etničke pripadnosti napustilo je Istočnu Hrvatsku i s izbjegličkim se statusom naselilo u Republici Srbiji. Tek se dio njih u procesu manjinskoga povratka vratio u (Istočnu) Hrvatsku. Treba, doduše, napomenuti da je dio demografskih ratnih gubitaka kompenziran doseljavanjem izbjeglica iz Bosne i Hercegovine, kao i Hrvata iz Republike Srbije, osobito iz Srijema. ${ }^{20}$

Tablica 2. Promjena broja stanovnika u zemlji Istočne Hrvatske po županijama između 2001. i 2011. godine

\begin{tabular}{|c|c|c|c|c|}
\hline \multirow{2}{*}{ Županija } & \multicolumn{2}{|c|}{ Broj stanovnika } & \multirow{2}{*}{$\begin{array}{l}\text { Apsolutna } \\
\text { promjena }\end{array}$} & \multirow{2}{*}{$\begin{array}{c}\text { Indeks } \\
\text { medupopisne } \\
\text { promjene }\end{array}$} \\
\hline & 2001. & 2011. & & \\
\hline Brodsko-posavska & 163489 & 158575 & -4914 & 97,0 \\
\hline Osječko-baranjska & 313406 & 305032 & -8374 & 97,3 \\
\hline Požeško-slavonska & 80389 & 78034 & -2355 & 97,1 \\
\hline Virovitičko-podravska & 90031 & 84836 & -5195 & 94,2 \\
\hline Vukovarsko-srijemska & 186185 & 179521 & -6664 & 96,4 \\
\hline Istočna Hrvatska & 833500 & 805998 & -27502 & 96,7 \\
\hline
\end{tabular}

IZVOR: Popisi stanovništva 2001. i 2011., DZSRH, Zagreb (www.dzs.hr); A. AKRAP, Promjene broja i prostornog razmještaja stanovništva Hrvatske i županija 1961. - 2011., u: V. PULJIZ, J. TICA i D. VIDOVIĆ (ur.), Migracije i razvoj Hrvatske. Podloga za hrvatsku migracijsku strategiju, Zagreb, 2014., 34-35.

Najsnažniji pad ukupnoga službenoga stanovništva ostvarila je Vukovarsko-srijemska županija (-12,2\%), a stanovništva $u$ zemlji Virovitičko-podravska županija $(-5,8 \%)$. U obama slučajevima najmanju ukupnu depopulaciju ostvarila je Osječko-baranjska županija (-7,7 \% prema konceptu ukupnoga službenoga broja stanovnika, odnosno, $-2,7 \%$ prema konceptu stanovništva $u$ zemlji). Prema intenzitetu međupopisne promjene ${ }^{21}$ ukupnoga službenoga stanovništva Osječko-baranjska,

${ }^{20}$ Detaljnije vidjeti u: D. ŽIVIĆ, Demografski ratni gubici kao determinanta razvoja stanovništva Istočne Hrvatske u razdoblju 1991. - 2001., u: Migracijske i etničke teme 21(2005.)1-2, 123-141.

${ }^{21}$ Prema intenzitetu međupopisne promjene broja stanovnika Ivo Nejašmić izdvaja, uz tip stagnacija, četiri progresivna i četiri regresivna tipa. Progresivni tipovi jesu: vrlo jaka progresija, jaka progresija, osrednja progresija i slaba progresija, dok su regresivni tipovi: slaba depopulacija, osrednja depopulaci- 
Brodsko-posavska, Požeško-slavonska i Virovitičko-podravska županija, kao i Istočna Hrvatska u cijelosti, imaju tip jaka depopulacija, dok Vukovarsko-srijemska županija ima najnegativniji tip - izumiranje. Prema konceptu stanovništva u zemlji Osječko-baranjsku i Požeško-slavonsku županiju karakterizira tip slaba depopulacija, a Vukovarsko-srijemsku, Brodsko-posavsku i Virovitičko-podravsku županiju te Istočnu Hrvatsku u cijelosti karakterizira tip osrednja depopulacija.

Dakle u apsolutnom smislu depopulacija Istočne Hrvatske u posljednjem međupopisju kretala se u rasponu od -27 502 do -85 261 stanovnika. Neovisno o iskazanoj razlici u obujmu depopulacije zbog primjene različitih kriterija međupopisne usporedbe, riječ je o zamjetnom gubitku stanovništva koji će posljedično izrazito nepovoljno djelovati i na druge dinamičke i strukturne sastavnice demografskoga razvoja Istočne Hrvatske, što se zorno prepoznaje i u projekcijama budućega kretanja stanovništva toga prostora.

\subsection{Prirodno kretanje Stanovništva - Prirodna depopulacija}

Prirodna depopulacija ili opadajuća (bio)reprodukcija stanovništva u užem smislu riječi drugi je suvremeni depopulacijski proces u istočnohrvatskim županijama. $\mathrm{Za}$ ocjenu dosegnute razine prirodne depopulacije uspostavili smo usporedivu vremensku seriju podataka o živorođenima i umrlima u razdoblju od 2001. do 2016. godine (slika 1).

U svih pet županija Istočne Hrvatske tijekom promatranoga razdoblja zabilježen je značajno veći broj umrlih osoba od živorođene djece. Ukupno je od 2001. do 2016. u istočnohrvatskim županijama živorođeno 126133 djece ili 7833 djece prosječno godišnje, umrlo je 167754 osoba ili 10485 prosječno godišnje, pa je ostvarena negativna prirodna promjena od -41621 stanovnika. To znači da je na godišnjoj razini prosječan demografski gubitak Istočne Hrvatske prirodnim putem u predmetnom razdoblju iznosio -2601 osobu, što je tri puta više od prosječne veličine istočnohrvatskih naselja prema popisu iz 2011. godine. Apsolutno najmanji broj živorođene djece zabilježen je 2016. godine (6439), pa je u odnosu na 2001. godinu (8750) pad nataliteta iznosio čak $-26,4 \%$, što znači da je u samo desetljeću i pol apsolutna rodnost u Istočnoj Hrvatskoj smanjena za četvrtinu. S obzirom na to da je mortalitet na godišnjoj razini stalno veći od 10000 umrlih osoba, razumljivo je da je prirodna depopulacija kontinuirani bioreprodukcijski proces, i to ne samo na razini Istočne Hrvatske nego i na razini svake pojedine istočnohrvatske županije (u svim je županijama svake godine u tematiziranom razdoblju broj umrlih osoba bio veći od broja živorođene djece). Ukupan prirodni pad stanovništva između 2001. i

ja, jaka depopulacija i izumiranje. Prema: I. NEJAŠMIĆ, Demogeografija - stanovništvo u prostornim odnosima i procesima, Zagreb, 2005. 
2016. u Brodsko-posavskoj županiji iznosio je -6436, u Osječko-baranjskoj županiji -17 317, u Požeško-slavonskoj županiji -4277, u Virovitičko-podravskoj županiji -6340 te u Vukovarsko-srijemskoj županiji -7350 stanovnika.

Opadajuću bioreprodukciju stanovništva potvrđuje i vitalni indeks, tj. broj živorođene djece na stotinu umrlih osoba (tablica 3). U svim je istočnohrvatskim županijama i u svim analiziranim godinama vrijednost vitalnoga indeksa bila niža od 100 . U prosjeku je u predmetnom razdoblju za Brodsko-posavsku županiju vitalni indeks iznosio 80,1; za Osječko-baranjsku županiju 72,6: za Požeško-slavonsku županiju 74,8; za Virovitičko-podravsku županiju 67,3 te za Vukovarsko-srijemsku županiju 80,1. Prosječan vitalni indeks za Istočnu Hrvatsku iznosio je 75,2; što znači da su u analiziranih 16 godina u prosjeku živorođena djeca uspjela nadomjestiti tek tri četvrtine broja umrlih. Osim toga sve županije bilježe gotovo kontinuirano smanjenje vrijednosti vitalnoga indeksa na godišnjoj razini pa je od 2001. do 2016. godine vitalni indeks u Brodsko-posavskoj županiji smanjen s 94,2 na 64,1; u Osječko-baranjskoj županiji s 83,7 na 62,9; u Požeško-slavonskoj županiji s 85,8 na 62,5; u Virovitičko-podravskoj županiji sa 70,7 na 61,9 te u Vukovarsko-srijemskoj županiji s 97,6 na 62,2.

Slika 1. Kretanje broja živorođenih, umrlih i prirodne promjene stanovništva Istočne Hrvatske između 2001. i 2016. godine

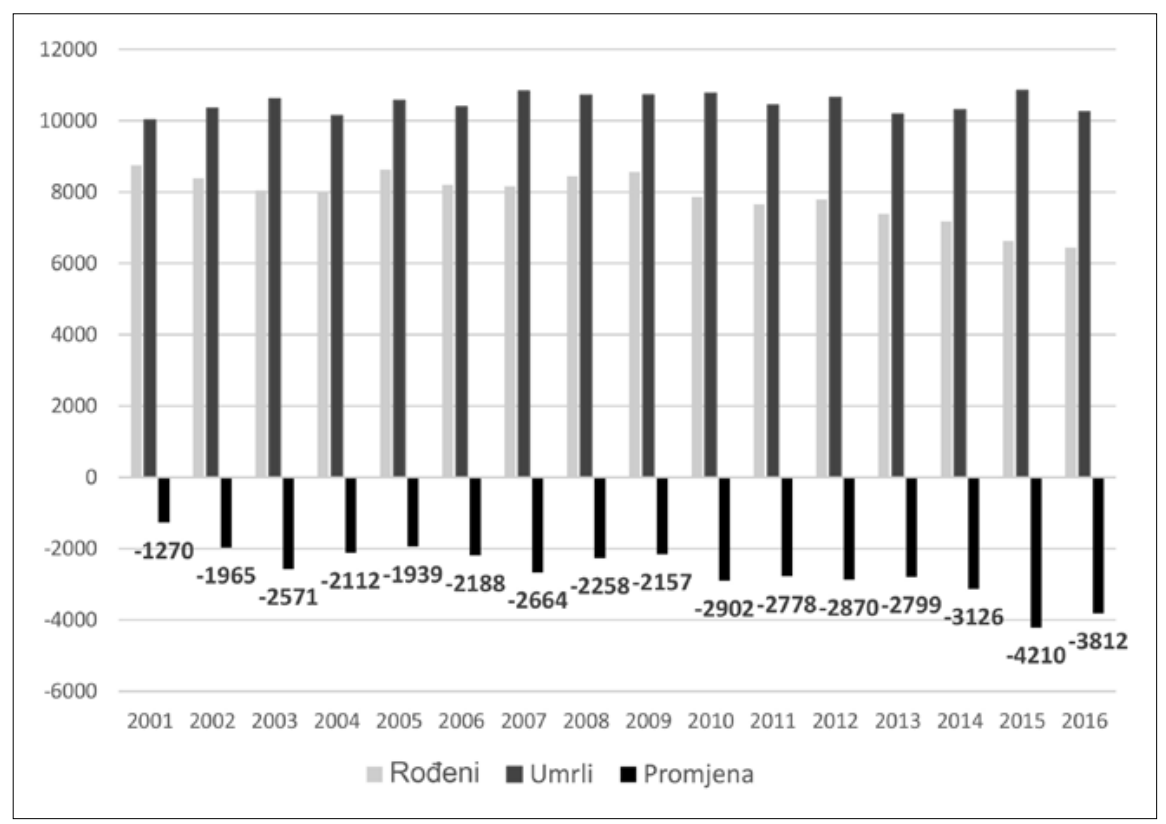

IZVOR: Priopćenja o prirodnom kretanju stanovništva Hrvatske, Vitalna statistika, DZSRH, Zagreb (www.dzs.hr). 
Prirodna depopulacija kao izrazito negativna odrednica ukupnoga kretanja stanovništva implicira značajne poremećaje $\mathrm{u}$ demografskom razvoju, napose $\mathrm{u}$ oblikovanju velikih (funkcionalnih) dobnih skupina, ubrzavajući pritom starenje stanovništva, s krajnje nepovoljnim učincima na društveno-gospodarski razvoj cijeloga prostora. Naime nizak natalitet $\mathrm{u}$ uvjetima brojčanoga jakoga iseljavanja determinira sve manji priljev stanovništva u dječju, a kasnije i u fertilnu dob. Time se u piramidi starosti ubrzano sužavaju mlađe dobne skupine, čime se bitno osiromašuju one dobne skupine koje nose nupcijalitet i buduću reprodukciju stanovništva. Ujedno se prirodne sastavnice ukupnoga kretanja stanovništva nalaze u stalnoj interakciji s mehaničkim kretanjem što implicira njihov zajednički nepovoljan učinak na pojavu i progrediranje ukupne depopulacije.

Tablica 3. Kretanje vitalnoga indeksa stanovništva Istočne Hrvatske po županijama između 2001. i 2016. godine

\begin{tabular}{|c|c|c|c|c|c|c|}
\hline Godina & 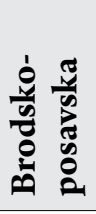 & 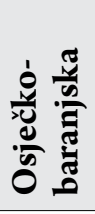 & 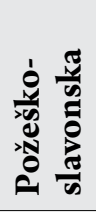 & 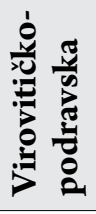 & 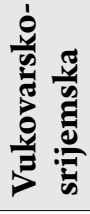 & 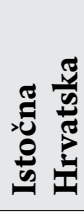 \\
\hline 2001. & 94,2 & 83,7 & 85,8 & 70,7 & 97,6 & 87,3 \\
\hline 2002. & 82,9 & 79,3 & 84,9 & 70,0 & 86,5 & 81,0 \\
\hline 2003. & 81,9 & 69,3 & 81,7 & 66,2 & 84,5 & 75,8 \\
\hline 2004. & 80,8 & 75,3 & 77,7 & 69,5 & 90,4 & 79,2 \\
\hline 2005. & 88,4 & 77,0 & 84,4 & 71,8 & 88,0 & 81,6 \\
\hline 2006. & 86,4 & 74,6 & 76,6 & 67,9 & 87,0 & 78,9 \\
\hline 2007. & 82,5 & 69,4 & 74,8 & 67,1 & 84,7 & 75,4 \\
\hline 2008. & 83,6 & 75,3 & 82,9 & 67,6 & 85,2 & 78,9 \\
\hline 2009. & 89,0 & 78,0 & 75,1 & 69,7 & 82,9 & 79,9 \\
\hline 2010 . & 76,1 & 70,3 & 72,3 & 69,1 & 77,7 & 73,0 \\
\hline 2011. & 82,5 & 72,4 & 66,1 & 65,5 & 74,8 & 73,4 \\
\hline 2012 . & 76,8 & 71,3 & 72,6 & 67,1 & 76,2 & 73,1 \\
\hline 2013. & 78,9 & 72,8 & 69,3 & 67,4 & 70,5 & 72,5 \\
\hline 2014. & 72,2 & 68,1 & 70,2 & 64,4 & 72,7 & 69,7 \\
\hline
\end{tabular}




\begin{tabular}{|c|c|c|c|c|c|c|}
\hline Godina & 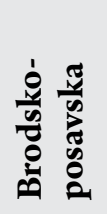 & 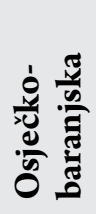 & 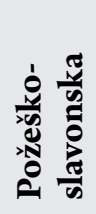 & 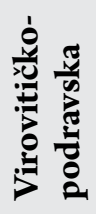 & 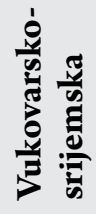 & 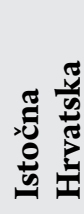 \\
\hline 2015. & 61,8 & 62,1 & 59,1 & 61,2 & 59,9 & 61,2 \\
\hline 2016. & 64,1 & 62,9 & 62,5 & 61,9 & 62,2 & 62,8 \\
\hline $\begin{array}{l}\text { Prosječna } \\
\text { vrijednost }\end{array}$ & 80,1 & 72,6 & 74,8 & 67,3 & 80,1 & 75,2 \\
\hline
\end{tabular}

IZVOR: Izračunao autor prema: Priopćenja o prirodnom kretanju stanovništva Hrvatske, Vitalna statistika, DZSRH, Zagreb (www.dzs.hr).

\subsection{MEHANiČKo KRETANJE STANOVNIŠTVA - EMIGRACIJSKA DEPOPULACIJA}

Migracije su u povijesti i razvoju stanovništva Istočne Hrvatske imale važnu ulogu. Ujedno je snažna bila i unutarnja prostorna pokretljivost, napose od druge polovice prošloga stoljeća kada jačaju migracije selo - grad (ruralni egzodus). Istočna Hrvatska danas je izrazito emigracijsko područje, s tim da se brojnije iseljavanje od doseljavanja bilježi već od ranih 1970-ih godina. ${ }^{22}$ Razlozi tomu, među ostalim, leže u promjeni smjera i intenziteta gospodarskoga i društvenoga razvoja, koji su dijelom posljedica naslijeđenih trendova i procesa u gospodarskoj dinamici (i ekonomskoj politici), te nedovoljno učinkovite tranzicije iz jugoslavenskoga i socijalističkoga u hrvatski i kapitalistički društveno-politički i ekonomski okvir. Smanjena potražnja za radnim mjestima uz porast nezaposlenosti uslijed nepovoljne gospodarske situacije i socijalne krize, loše poduzetničke klime i nemogućnosti pronalaženja zaposlenja u profesiji, osobito mladima, snažno je utjecala na jačanje emigracijskih struja istočnohrvatskoga stanovništva kojima svjedočimo unatrag nekoliko godina. »Postojeći odljev mladog i obrazovanog stanovništva, kao i iskazano planirano ostvarivanje egzistencije u nekom drugom području Hrvatske ili inozemstvu, objektivna su prijetnja budućemu gospodarsko-socijalnom razvoju, s mogućim odrazom u daljnjem produbljivanju zaostajanja Istočne Hrvatske u regionalnom razvoju zemlje «, s pravom će upozoriti M. Matišić i D. Pejnović. ${ }^{23}$

\footnotetext{
${ }^{22}$ Usp. A. WERTHEIMER-BALETIĆ, Demografski razvoj Slavonije i Baranje, 90-104.

${ }^{23}$ M. MATIŠIĆ, D. PEJNOVIĆ, Uzroci i posljedice zaostajanja Istočne Hrvatske u regionalnom razvoju Hrvatske, 135.
} 
Imajući u vidu važnost i složenost mehaničkoga kretanja stanovništva, korisnim držimo primjenom znanstveno relevantne vitalno-analitičke demografske metode procijeniti grubu migracijsku bilancu za razdoblje 2001. - 2011. godine prema dvama popisnim načelima: načelu ukupnoga službenoga broja stanovnika i načelu prisutnoga stanovništva (stanovništvo $u$ zemlji). Pritom se želi upozoriti na sljedeće: prvo, na egzaktan doprinos izračunane grube migracijske bilance ukupnom kretanju stanovništva, tj. ukupnoj depopulaciji Istočne Hrvatske, drugo, na razlike u veličini (obujmu) grube migracijske bilance između pojedinih istočnohrvatskih županija u promatranom međupopisju. Stoga su izrađene dvije analitičke tablice za procjenu grube migracijske bilance (tablice 4 i 5 ).

(a) Migracijska bilanca prema načelu ukupnoga službenoga broja stanovnika:

Prema navedenom načelu Istočna Hrvatska ostvarila je negativnu grubu migracijsku bilancu od čak -62 856 stanovnika, što znači da je u ukupnoj depopulaciji prirodni pad stanovništva činio $26,3 \%$, a veće iseljavanje od doseljavanja $73,7 \%$ demografskoga regresa. To indicira emigracijski tip razvoja naseljenosti, odnosno najnepovoljniji tip općega kretanja stanovništva - trend izumiranja. Sve istočnohrvatske županije, očekivano, zabilježile su negativnu grubu migracijsku bilancu, tj. veće iseljavanje od doseljavanja stanovništva, pa je i opće kretanje stanovništva u njima imalo izrazita egzodusna obilježja (trend izumiranja). U svim je županijama prema konceptu ukupnoga službenoga broja stanovnika mehaničko kretanje dominantan čimbenik ukupne depopulacije. Negativna gruba migracijska bilanca činila je tako 82,5\% ukupne depopulacije u Brodsko-posavskoj županiji, 61,1 \% ukupne depopulacije u Osječko-baranjskoj, 71,9\% ukupne depopulacije u Požeško-slavonskoj, 54,6 \% ukupne depopulacije u Virovitičko-podravskoj te - najviše - čak 87,2 \% ukupne depopulacije u Vukovarsko-srijemskoj županiji.

(b) Migracijska bilanca prema načelu stanovništva u zemlji:

Procjena grube migracijske bilance stanovništva Istočne Hrvatske prema načelu prisutnosti pokazuje drukčija, naizgled povoljnija obilježja. Naime između 2001. i 2011. broj stanovnika $u$ zemlji u pet istočnohrvatskih županija smanjen je za 27502 osobe; istodobno je prirodna promjena iznosila -22 405 stanovnika, tako da je gruba migracijska bilanca procijenjena na svega -5098 osoba, što je manje od $10 \%$ negativne migracijske bilance ukupnoga službenoga broja stanovnika. Unatoč tomu tip općega kretanja stanovništva i dalje je najnegativniji - trend izumiranja. U ukupnoj depopulaciji prirodno smanjenje sudjelovalo je s $81,5 \%$, a negativna migracijska bilanca s $18,5 \%$. Treba naglasiti da je prema načelu prisutnosti Osječko-baranjska županija zabilježila pozitivnu grubu migracijsku bilancu, pa je i tip općega kretanja stanovništva bio pozitivan - trend 
vrlo slabe regeneracije imigracijom. U ostalim istočnohrvatskim županijama tip općega kretanja i dalje je egzodusni - trend izumiranja. Osobito je teška situacija u Vukovarsko-srijemskoj županiji, čija negativna gruba migracijska bilanca čini više od dvije trećine $(67,2 \%)$ ukupne negativne grube migracijske bilance Istočne Hrvatske i jedina je među istočnohrvatskim županijama u kojoj je mehaničko kretanje stanovništva i dalje dominantan čimbenik ukupne depopulacije. Gruba negativna migracijska bilanca u ukupnoj depopulaciji Vukovarsko-srijemske županije sudjelovala je s $51,4 \%$. U preostalim je istočnohrvatskim županijama, prema načelu prisutnosti, dominantan čimbenik ukupne depopulacije prirodni pad stanovništva. Prirodno je smanjenje stanovništva u Brodsko-posavskoj županiji činilo 64,9 \% ukupne depopulacije, u Požeško-slavonskoj županiji čak 93,0 \% ukupne depopulacije te u Virovitičko-podravskoj županiji 74,8 \% ukupne depopulacije stanovništva $u$ zemlji.

Tablica 4. Radna tablica za izračun migracijske bilance stanovništva Istočne Hrvatske po županijama 2001. - 2011.

(koncept ukupnoga službenoga broja stanovnika)

\begin{tabular}{|c|c|c|c|c|c|c|}
\hline \multirow[b]{2}{*}{ Županija } & \multirow{2}{*}{ 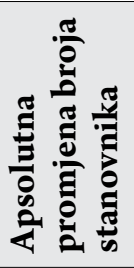 } & \multirow{2}{*}{ 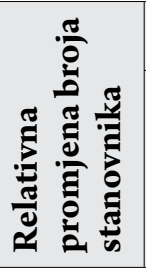 } & \multicolumn{2}{|c|}{ Prirodna promjena } & \multicolumn{2}{|c|}{ Migracijska bilanca } \\
\hline & & & 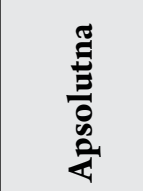 & 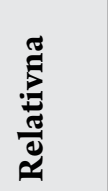 & 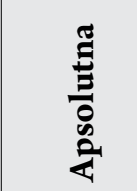 & 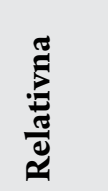 \\
\hline Brodsko-posavska & -18190 & $-10,3$ & -3188 & $-1,8$ & -15002 & $-8,5$ \\
\hline Osječko-baranjska & -25474 & $-7,7$ & -9906 & $-3,0$ & -15568 & $-4,7$ \\
\hline Požeško-slavonska & -7797 & $-9,1$ & -2189 & $-2,6$ & -5608 & $-6,5$ \\
\hline Virovitičko-podravska & -8553 & $-9,2$ & -3886 & $-4,2$ & -4667 & $-5,0$ \\
\hline Vukovarsko-srijemska & -25247 & $-12,3$ & -3236 & $-1,6$ & -22011 & $-10,7$ \\
\hline Istočna Hrvatska & -85261 & $-9,6$ & -22405 & $-2,5$ & -62856 & $-7,1$ \\
\hline
\end{tabular}


Tablica 5. Radna tablica za izračun migracijske bilance stanovništva Istočne Hrvatske po županijama 2001. - 2011. (koncept stanovništva u zemlji)

\begin{tabular}{|c|c|c|c|c|c|c|}
\hline \multirow[b]{2}{*}{ Županija } & \multirow{2}{*}{ 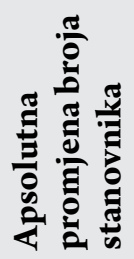 } & \multirow{2}{*}{ 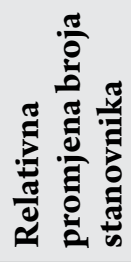 } & \multicolumn{2}{|c|}{ Prirodna promjena } & \multicolumn{2}{|c|}{ Migracijska bilanca } \\
\hline & & & 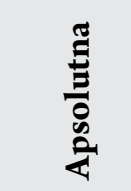 & 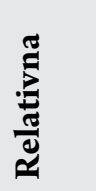 & 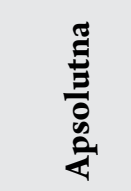 & 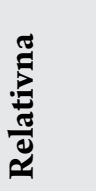 \\
\hline Brodsko-posavska & -4914 & $-3,0$ & -3188 & $-1,9$ & -1726 & $-1,1$ \\
\hline Osječko-baranjska & -8374 & $-2,7$ & -9906 & $-3,2$ & 1532 & 0,5 \\
\hline Požeško-slavonska & -2355 & $-2,9$ & -2189 & $-2,7$ & -166 & $-0,2$ \\
\hline Virovitičko-podravska & -5195 & $-5,8$ & -3886 & $-4,3$ & -1310 & $-1,5$ \\
\hline Vukovarsko-srijemska & -6664 & $-3,6$ & -3236 & $-1,7$ & -3428 & $-1,8$ \\
\hline Istočna Hrvatska & -27502 & $-3,3$ & -22405 & $-2,7$ & -5098 & $-0,6$ \\
\hline
\end{tabular}

\section{Biološka struktura stanovništva - demografsko starenje}

Biološka (demografska) struktura stanovništva najpotpunije odražava prošli, sadašnji i budući razvoj neke populacije. Naime dobni sastav (uz spolni) najvažnija je dugoročna demografska determinanta reprodukcije i ekonomske aktivnosti stanovništva. A. Wertheimer-Baletić upozorava da su »procesi depopulacije (ukupni i parcijalni) u stalnoj /su/ i čvrstoj interakciji s promjenama u dobnoj strukturi stanovništva, uz interakciju koja postoji i s drugim strukturama (demografskim i ekonomsko-socijalnim) $\ll^{24}$

$\mathrm{Za}$ ocjenu međupopisne promjene u razvoju dobne strukture stanovništva Istočne Hrvatske u razdoblju 2001. - 2011. izračunani su jednostavni, ali referentni pokazatelji (koeficijent mladosti, ${ }^{25}$ koeficijent starosti, ${ }^{26}$ indeks starenja, ${ }^{27}$ prosječna sta-

${ }^{24}$ A. WERTHEIMER-BALETIĆ, Depopulacija i starenje stanovništva - temeljni demografski procesi u Hrvatskoj, 642.

${ }^{25} \mathrm{U}$ ovom radu koeficijent mladosti predstavlja relativan udio stanovništva do 19. godine starosti (mlado stanovništvo) u ukupnom stanovništvu.

${ }^{26} \mathrm{U}$ ovom radu koeficijent starosti predstavlja relativan udio stanovništva starog 60 i više godina (staro stanovništvo) u ukupnom stanovništvu.

${ }^{27}$ Indeks starenja u ovom radu izračunan je kao kvocijent broja stanovnika do 19. godine starosti u odnosu na broj stanovnika koji su stari 60 i više godina. U demografskoj literaturi vrijednost indeksa starenja 40 (ili 0,40$)$ uzima se graničnom u kontekstu pojave i razvoja procesa starenja stanovništva. 
rost) koji indiciraju uznapredovao proces demografskoga starenja ${ }^{28}$, koji je i faktor i posljedica složenih odnosa proizišlih iz uske povezanosti demoreproduktivnih i migracijskih procesa (tablica 6 i slike 2 i 3 ). Naime struktura stanovništva po dobi (i spolu) determinirana je sastavnicama ukupnoga kretanja stanovništva, tj. prirodnom dinamikom (natalitet/fertilitet i mortalitet) i migracijama, ali i sama na njih izravno utječe. Osim toga dobna struktura utječe i na sva područja društvenoga života, osobito na njezinu ekonomsku, socijalnu i kulturnu dimenziju. ${ }^{29}$

Izračunani indikatori sastava stanovništva Istočne Hrvatske po dobi nedvosmisleno upućuju na progrediranje procesa starenja kao negativne odrednice demografskoga, društvenoga i gospodarskoga razvoja, na koji je, kao i u slučaju ukupnoga hrvatskoga stanovništva, utjecao $\gg$ niz dugoročno nepovoljnih činitelja $(. .$.$) , među$ kojima je na prvom mjestu iseljavanje i ubrzani pad fertiliteta $(. ..) \ll .{ }^{30}$

Između 2001. i 2011. kontingent mladoga stanovništva smanjen je za $20,4 \%$, pa je i koeficijent mladosti smanjen s 25,78 na 22,71. U istom je međupopisju i kontingent staroga stanovništva smanjen, ali neznatno $(-0,2 \%)$, pa je koeficijent starosti povećan s 20,87 na 23,03 . Porast vrijednosti indeksa starenja (s 80,90 na 101,41$)$ jasno pokazuje da je, u demografskom kontekstu, staro stanovništvo postalo brojnije od mladoga, što ima brojne nepovoljne demografske i ekonomske učinke. Rezultati popisa 2011. godine pokazali su da je u Osječko-baranjskoj i Virovitičko-podrav-

Populacije čiji je indeks starenja veći od 40 u procesu su demografskoga starenja različitoga intenziteta. U osobito nepovoljnoj situaciji jesu populacije kod kojih je vrijednost indeksa starenja veća od 100 jer je u tom slučaju staro stanovništvo brojnije od mladoga, što u perspektivi vodi k potpunoj inverziji dobnoga sastava. Piramida starosti tada poprima izrazito restriktivni oblik urne. Već prema rezultatima popisa iz 2011. godine broj stanovnika Istočne Hrvatske starih 75 i više godina (61 585) bio je za $54 \%$ veći od broja djece u dobi do 4 . godine života (40 000), s tim da je između 2001. i 2011. godine obujam stanovništva iznad 75 godina povećan za $48,6 \%$ (priljev brojnijih naraštaja rođenih u kompenzacijskom razdoblju nakon 2. svjetskoga rata te produljenja ljudskoga vijeka), a obujam kontingenta djece do 4. godine smanjen za 24,1 \% (izravna posljedica niskoga nataliteta).

${ }^{28}$ Pod starenjem stanovništva ponajčešće se razumijeva usporedni proces smanjivanja broja i relativnoga udjela mladoga, a povećanja broja i relativnoga udjela staroga stanovništva. Najvažnija odrednica demografskoga starenja jest proces dugotrajnoga smanjivanja fertiliteta i nataliteta, što se u evolutivnom smislu prvo očituje u generacijskoj depopulaciji ženskoga, a potom i kroz generacijsku depopulaciju ukupnoga stanovništva. Druga bitna determinanta starenja jest produljenje ljudskoga vijeka zbog pozitivnih učinaka razvoja zdravstvene zaštite i medicine, farmacije i genetike te promoviranja zdravih načina života. Usp. D. ŽIVIĆ, I. TURK, N. ŠIMUNIĆ, Promjene u dobnom sastavu stanovništva Hrvatske kao indikator demografskoga starenja, u: Čovjek i smrt. Teološki, filozofski, bioetički i društveni pristup, Zagreb, 2017., 531-550.

${ }^{29}$ S. PODGORELEC, S. KLEMPIĆ, Starenje i neformalna skrb o starim osobama u Hrvatskoj, u: Migracijske i etničke teme 23(2007.)1-2, 111-134.

${ }^{30}$ A. AKRAP, Aktivni osiguranici i umirovljenici u Hrvatskoj - očekivani trendovi do 2031. godine, u: Revija za socijalnu politiku 13(2006.)2, 128. 
skoj županiji indeks starenja premašio vrijednost 100, a da je u Brodsko-posavskoj, Požeško-slavonskoj i Vukovarsko-srijemskoj županiji tek nešto malo ispod te vrijednosti. Potonje nas dovodi do zaključka da je Istočna Hrvatska, kao i sve njezine županije, u izrazito dubokoj demografskoj ostarjelosti, s nepovoljnim perspektivama zbog sve nižega nataliteta, a sve brojnijega iseljavanja mladoga stanovništva.

Ubrzano starenje, izazvano sve slabijom bioreprodukcijom, kao i jačanjem emigracije, ne dovodi do potrebnoga i/ili poželjnoga obnavljanja funkcionalnih dobnih skupina neophodnih za reprodukciju (fertilni kontingenti), kao i za formiranje radno sposobnih i radno aktivnih kontingenata stanovništva (radna snaga). Treba posebno upozoriti da starenje ukupnoga stanovništva ujedno znači i starenje pojedinih relevantnih funkcionalnih dobnih kontingenata, primjerice fertilnoga i radnoga kontingenta, što produbljuje poremećaje u formiranju uravnoteženoga demografskoga okvira bioreprodukcije i ekonomske strukture stanovništva, tj. radne snage. U tim uvjetima, dakako, značajno slabi reproduktivni potencijal populacije, ali i ekonomska aktivnost stanovništva što je, uz ratne posljedice, jedan od negativnih činitelja ukupnoga demografskoga i gospodarskoga zaostajanja Istočne Hrvatske.

Zbog toga se u dugoročnom smislu mogu očekivati novi problemi u dinamici nataliteta, ali i u osiguranju dovoljno brojne radne snage na tržištu rada. Naime $\mathrm{s}$ jedne strane nedostatak mladih kao posljedica sve skromnije bioreprodukcije, poglavito u kontekstu sve nižega fertiliteta i nataliteta, vodi k sužavanju demoreproduktivne osnovice, tj. neobnavljanju fertilnih i radno sposobnih kontingenata stanovništva barem u obujmu koji omogućava jednostavnu reprodukciju. Primjerice u predmetnom je razdoblju broj žena do 14. godine starosti smanjen za $21,8 \%$, a u fertilnom razdoblju (od 15. do 49.) za 14,8 \%, dok je u postfertilnom razdoblju (50 godina i starije) povećan za 3,5\%. Prema popisu 2011. samo 15,3 \% ženskoga stanovništva Istočne Hrvatske nalazilo se u predfertilnoj dobi koja predstavlja demoreproduktivni okvir buduće bioreprodukcije. S druge strane čak $41,0 \%$ žena nalazilo se u postfertilnoj dobi kada je rađanje vrlo rijetka, gotovo zanemariva pojava.

Ujedno sve snažniji priljev stanovništva u stariju i uglavnom ekonomski neaktivnu dob (60 ili 65 godina i stariji $)^{31}$ dugoročno će još više pojačati pritisak tih naraštaja

${ }^{31}$ Broj stanovnika Istočne Hrvatske do 14. godine života u predmetnom je razdoblju smanjen za $21,5 \%$, kao i broj stanovnika u radno sposobnoj dobi (od 15. do 64.) - za 8,5 \%. Nasuprot njima, broj stanovnika u postradnoj dobi (65 godina i stariji) povećan je za 3,2 \%. Posebno je zabrinjavajuće to što je već prema posljednjem popisu kontingent stanovništva u postradnoj dobi za gotovo $6 \%$ bio veći od dječje populacije, što nesumnjivo potvrđuje bojaznost o skoroj inverziji dobnoga sastava istočnohrvatskoga stanovništva. 
na fondove mirovinskoga, ${ }^{32}$ socijalnoga i zdravstvenoga sustava ${ }^{33}$ koji će sa stajališta koncepta međugeneracijske solidarnosti, ako se nastave dosadašnji demografski trendovi, uskoro biti posve neodrživi. To, naravno, u prvi plan postavlja i pitanje prilagodbe i održivosti institucionalne i izvaninstitucionalne skrbi o starim osobama, ${ }^{34}$ ali i pitanje uspostavljanja i promicanja koncepta aktivnoga starenja. ${ }^{35}$

Tablica 6. Odabrani indikatori biološke strukture stanovništva Istočne Hrvatske prema popisima iz 2001. i 2011. godine

\begin{tabular}{|l|r|r|c|}
\hline \multicolumn{1}{|c|}{ Indikatori } & 2001. & 2011. & Indeks promjene \\
\hline Ukupan broj stanovnika & 891259 & 805998 & 90,43 \\
\hline Broj muškaraca & 429178 & 389552 & 90,77 \\
\hline Broj žena & 462081 & 416446 & 90,12 \\
\hline Koeficijent feminiteta & 107,67 & 106,90 & - \\
\hline Koeficijent maskuliniteta & 92,88 & 93,54 & - \\
\hline Broj stanovnika do 19 godina & 229808 & 183038 & 79,65 \\
\hline Broj stanovnika starijih od 60 godina & 185991 & 185615 & 99,80 \\
\hline Koeficijent mladosti & 25,78 & 22,71 & - \\
\hline Koeficijent starosti & 20,87 & 23,03 & - \\
\hline
\end{tabular}

\footnotetext{
${ }^{32}$ Projicirajući očekivane trendove u kretanju broja aktivnih osiguranika i umirovljenika u Hrvatskoj do 2031., A. Akrap upozorava da će buduće kretanje broja umirovljenika ovisiti, dakako, o sve nepovoljnijim demografskim trendovima (napose glede nataliteta), ali i o stanju gospodarstva, tj. o ekonomskim kretanjima. Pritom naglašava da »gospodarska kriza potiče odlazak u mirovinu, a s dinamičnijim gospodarskim rastom rast će broj aktivnih osiguranika i, suprotno tome, smanjivat će se priljev korisnika prijevremenih starosnih mirovina «. A. AKRAP, Aktivni osiguranici i umirovljenici u Hrvatskoj - očekivani trendovi do 2031. godine, 143.

${ }^{33}$ Kako naglašava V. Puljiz, »uslijed starenja stanovništva u osjetnom su porastu javni troškovi koje europske države izdvajaju za potrebe starih ljudi (... ) To su izdaci za mirovine, koji su najveći, potom zdravstveni troškovi, zatim troškovi dugotrajne skrbi, obrazovni troškovi te izdaci za naknade starim ljudima za nezaposlenost. Naravno, starenje stanovništva uzrokovat će i povećanje privatnih socijalnih troškova «. V. PULJIZ, Starenje stanovništva - izazov socijalne politike, u: Revija za socijalnu politiku 23(2016.)1, 81-98., ovdje 89.

${ }^{34}$ Detaljnije vidjeti u: S. PODGORELEC, S. KLEMPIĆ, Starenje i neformalna skrb o starim osobama u Hrvatskoj, 111-134.

${ }^{35}$ Prema V. Puljizu aktivno je starenje $\gg$ koncept koji je danas široko prihvaćen kao polazišni okvir socijalne politike prema starim ljudima «. (V. PULJIZ, Starenje stanovništva - izazov socijalne politike, 93). Koncept aktivnoga starenja uobičajeno podrazumijeva: produljenje radnoga vijeka, cjeloživotno obrazovanje te sudjelovanje u društvenom i kulturnom životu.
} 
- D. Živić, Depopulacija i starenje u Istočnoj Hrvatskoj, STR. 657-679.

\begin{tabular}{|l|r|r|c|}
\hline \multicolumn{1}{|c|}{ Indikatori } & \multicolumn{1}{|c|}{$\mathbf{2 0 0 1 .}$} & $\mathbf{2 0 1 1 .}$ & Indeks promjene \\
\hline Indeks starenja & 80,9 & 101,41 & 125,35 \\
\hline Broj žena do 14 godina & 81456 & 63698 & 78,20 \\
\hline Broj žena od 15 do 49 godina & 213416 & 181909 & 85,24 \\
\hline Broj žena starijih od 50 godina & 165121 & 170839 & 103,46 \\
\hline Udio predfertilnoga kontingenta & 17,63 & 15,30 & - \\
\hline Udio fertilnoga kontingenta & 46,19 & 43,68 & - \\
\hline Udio postfertilnoga kontingenta & 35,73 & 41,02 & - \\
\hline Broj stanovnika do 14 godina & 166734 & 130954 & 78,54 \\
\hline Broj stanovnika od 15 do 64 godina & 586484 & 536431 & 91,47 \\
\hline Broj stanovnika starijih od 65 godina & 134311 & 138613 & 103,20 \\
\hline Udio predradnoga kontingenta & 18,71 & 16,25 & - \\
\hline Udio radnoga kontingenta & 65,81 & 66,55 & - \\
\hline Udio postradnoga kontingenta & 15,07 & 17,20 & - \\
\hline
\end{tabular}

IZVOR: Popisi stanovništva 2001. i 2011., DZSRH, Zagreb (www.dzs.hr).

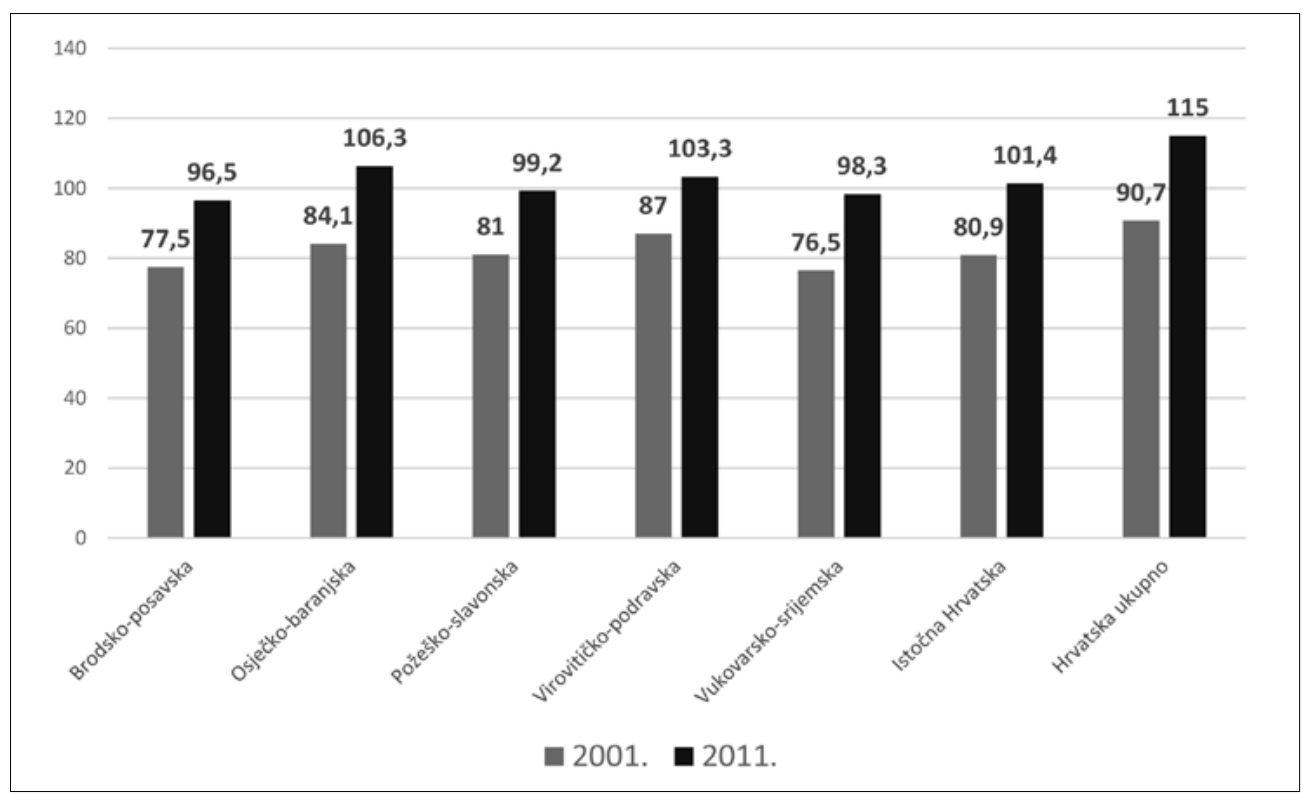

Slika 2. Promjena vrijednosti indeksa starenja 2001. - 2011. godine po županijama Istočne Hrvatske 


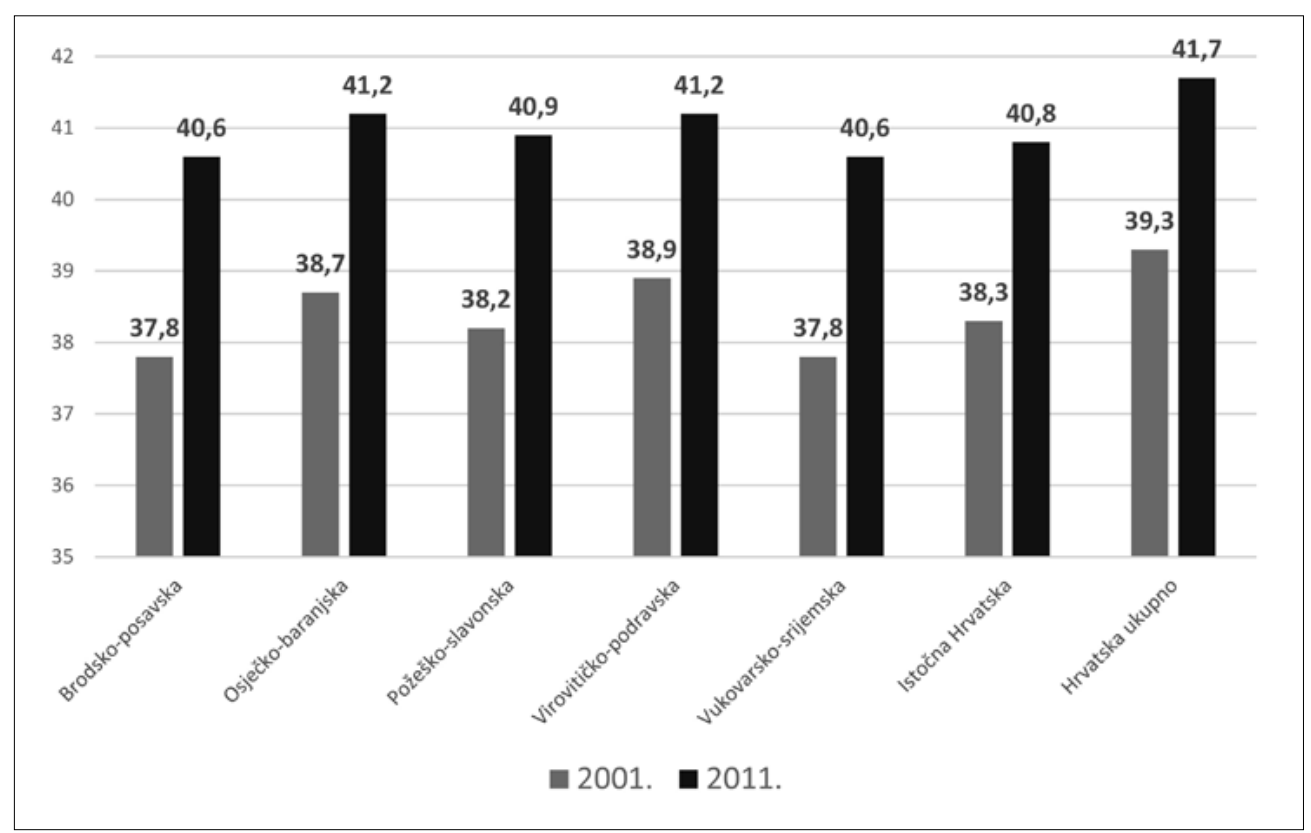

Slika 3. Promjena prosječne starosti 2001. - 2011. godine po županijama Istočne Hrvatske

\section{Umjesto zaključka}

Prema relevantnim demografskim statističkim indikatorima, izračunanim i opisanim u prethodnoj demografskoj analizi, razvidno je da se Istočna Hrvatska u cijelosti, kao i svaka njezina pojedina županija, nalazi u procesu depopulacije, tj. karakterizira ju opadajuća reprodukcija stanovništva u širem smislu riječi, i to u svim trima njezinim dinamičkim vidovima: ukupnom, prirodnom i emigracijskom. S obzirom na to da se opći i parcijalni procesi depopulacije nalaze u snažnom korelativnom odnosu spram oblikovanja biološke strukture stanovništva (dob i spol), odnosno pojave i produbljenja procesa demografskoga starenja, jasno je da oni, sinergijski gledano, čine prevladavajuće dalekosežne regresivne čimbenike populacijskoga, a time i društveno-gospodarskoga razvoja Istočne Hrvatske. S obzirom na to da su sve istočnohrvatske županije u procesu/trendu depopulacije, analizirani prostor karakterizira vrlo visok stupanj prostorne depopulacijske homogenosti.

Ukupna depopulacija i starenje stanovništva najvažniji su procesi koji karakteriziraju suvremene demografske promjene na tom prostoru, a relevantne projekcije budućega kretanja stanovništva (tablica 7), izrađene u kontekstu izostanka značajnijih i dugoročnijih društvenih intervencija u područje nataliteta/fertiliteta, kao i izostanka snažnijega gospodarskoga rasta (koji bi usporio iseljavanje), indiciraju 
nastavak nepovoljnih dinamičkih i strukturno-demografskih trendova. ${ }^{36}$ Tako će do sredine 21. stoljeća, a u odnosu na popis iz 2011. godine, stopa ukupne depopulacije u Brodsko-posavskoj županiji iznositi -32,8 \%, u Osječko-baranjskoj županiji -24,9 \%, u Požeško-slavonskoj županiji -49,3 \%, u Virovitičko-podravskoj županiji $-39,6 \%$ i Vukovarsko-srijemskoj županiji -38,5 \% te u Istočnoj Hrvatskoj ukupno $-33,4 \%$. Ako se nastave dosadašnji nepovoljni demografski trendovi, osobito u bioreprodukciji, realno se može očekivati da će Istočna Hrvatska do sredine 21. stoljeća prirodnim i mehaničkim putem (iseljavanjem) izgubiti (najmanje) trećinu stanovništva popisanoga 2011. godine.

Ujedno očekivani daljnji pad broja stanovnika istočnohrvatskih županija ne će biti linearan, nego se očekuje jačanje debalansa u odnosu između pojedinih velikih (funkcionalnih) dobnih kontingenata, osobito u odnosu: mlado - staro stanovništvo (tablica 8).$^{37}$ Primjerice do 2030. godine koeficijent mladosti past će na 18,5; a koeficijent starosti povećati se na 30,0; što znači da će gotovo trećina stanovništva Istočne Hrvatske ubrzo biti starija od 60 godina. Indeks starenja upozorava da bi do 2030. godine na 100 stanovnika do 19. godine moglo dolaziti čak 162 osobe stare 60 godina i više. Očekuje se također da će gotovo četvrtina (23,3\%) ukupnoga stanovništva Istočne Hrvatske biti starija od 65 godina, a 2,5\% starija od 85 godina. Prosječna će starost biti tek nešto niža od 45 godina. Produbit će se i debalansi u odnosu između funkcionalnih dobnih skupina ženskoga stanovništva prema fertilnosti. Naime relativan udio fertilnoga kontingenta past će ispod $40 \%$, dok će relativan udio postfertilnoga kontingenta dosegnuti gotovo polovicu ukupnoga ženskoga stanovništva Istočne Hrvatske. Pritom će relativan udio djevojčica jedva premašiti $13 \%$. To znači da će žene stare 50 i više godina za desetak i nešto više godina predvidivo biti 3,5 puta brojnije od žena (djevojčica) u dobi do 14. godine života. Sve to ukazuje na produbljenje poremećaja u dobnom sastavu stanovništva, na ubrzanje demografskoga starenja te na dodatno sužavanje demoreproduktivne osnovice istočnohrvatskoga stanovništva.

U tom kontekstu sasvim se ozbiljnim nameće pitanje: Postoje li u Istočnoj $\mathrm{Hr}$ vatskoj bilo kakve vlastite demografske rezerve koje bi mogle ili trebale pokrenuti populacijsku revitalizaciju? Ako postoje, mogu li se aktivirati bez značajnije, dugoročnije, cjelovitije i sustavnije populacijske, obiteljske i ekonomske politike koje bi bile usmjerene na poticanje rađanja, usporavanje iseljavanja i osiguranje uvjeta za imigraciju novoga stanovništva iz drugih dijelova Hrvatske ili hrvatskoga iseljeništva sukladno hrvatskim nacionalnim i strateškim interesima. A svakako bi hrvatski nacionalni interes trebao biti usporavanje i u konačnici zaustavljanje demografskoga pražnjenja istočnoga ravničarskoga i panonskoga krila zemlje.

\footnotetext{
${ }^{36}$ Detaljnije vidjeti u: A. AKRAP, Demografski slom Hrvatske: Hrvatska do 2051., 855-881.

${ }^{37}$ Usp. I. ČIPIN i suradnici, Stručna podloga za izradu Strategije prostornog razvoja Republike Hrvatske: demografski scenarij i migracije, Zagreb, 2014.
} 
Tablica 7. Projekcija broja stanovnika Istočne Hrvatske do 2051. godine po županijama

\begin{tabular}{|l|r|r|r|r|r|c|}
\hline \multicolumn{1}{|c|}{ Županija } & 2011. & 2021. & 2031. & 2041. & 2051. & $\begin{array}{c}\text { Indeks } \\
\text { 2051./2011. }\end{array}$ \\
\hline Brodsko-posavska & 158575 & 148032 & 136727 & 122576 & 106496 & 67,2 \\
\hline Osječko-baranjska & 305032 & 293087 & 276336 & 254088 & 229136 & 75,1 \\
\hline Požeško-slavonska & 78034 & 69809 & 61067 & 50754 & 39601 & 50,7 \\
\hline Virovitičko-podravska & 84836 & 78281 & 70764 & 61451 & 51217 & 60,4 \\
\hline Vukovarsko-srijemska & 179521 & 165647 & 150177 & 131398 & 110394 & 61,5 \\
\hline UKUPNO & 805998 & 754856 & 695071 & 620267 & 536844 & 66,6 \\
\hline
\end{tabular}

IZVOR: A. AKRAP, Demografski slom Hrvatske: Hrvatska do 2051., Bogoslovska smotra, 85(2015.)3, 862 .

Tablica 8. Odabrani indikatori strukture stanovništva Istočne Hrvatske prema popisima 2001. i 2011. godine te projekciji za 2030. godinu

\begin{tabular}{|l|c|c|c|}
\hline \multicolumn{1}{|c|}{ Indikatori } & $\mathbf{2 0 0 1 .}$ & $\mathbf{2 0 1 1 .}$ & $\begin{array}{c}\text { Projekcija } \\
\mathbf{2 0 3 0 .}\end{array}$ \\
\hline Koeficijent mladosti & 25,8 & 22,7 & 18,5 \\
\hline Koeficijent starosti & 20,9 & 23,0 & 30,0 \\
\hline Indeks starenja & 80,9 & 101,4 & 162,4 \\
\hline Udio stanovništva do 14. godine & 18,7 & 16,3 & 13,4 \\
\hline Udio stanovništva 65 godina i stariji & 15,1 & 17,2 & 23,3 \\
\hline Udio stanovništva 85 godina i stariji & 0,7 & 1,1 & 2,5 \\
\hline Prosječna starost & 38,3 & 40,8 & 44,6 \\
\hline Udio žena do 14. godine & 17,6 & 15,3 & 13,3 \\
\hline Udio žena od 15. do 49. godine & 46,2 & 43,7 & 39,5 \\
\hline Udio žena 50 godina i starije & 35,7 & 41,0 & 47,3 \\
\hline
\end{tabular}

IZVOR: Popisi stanovništva 2001. i 2011., DZSRH, Zagreb (www.dzs.hr); I. ČIPIN i suradnici, Stručna podloga za izradu Strategije prostornog razvoja Republike Hrvatske: demografski scenarij i migracije, Zagreb: Sveučilište u Zagrebu, Ekonomski fakultet, Katedra za demografiju, 2014. 


\section{DEPOPULATION AND AGING IN EASTERN CROATIA}

\section{Dražen ŽIVIĆ*}

Summary: The subject of this study is the total population trends and contemporary changes in the biological structure of the population of Eastern Croatia. The purpose of the study is, based on the results of the last two censuses (2001 and 2011), the analysis of vital statistics for the period 2001-2016, and the projections of the future population trends (by 2030, and 2051) to determine, analyze and interpret basic aggregate indicators indicating trends in the general, natural and mechanical movement of the population of Eastern Croatia and their interactive link with the process of demographic aging. The aim of the paper is to establish and describe the reached level of total depopulation and demographic aging of Eastern Croatia. Given that general and partial depopulation processes are in strong correlation with the formation of the biological structure of the population, it is clear that together they form far-reaching regressive factors of population development, as well as socio-economic development of Eastern Croatia. If the current unfavorable demographic trends persist, especially in bio-reproduction, it is reasonable to expect that Eastern Croatia by the middle of the $21^{\text {st }}$ century will naturally and mechanically lose one third of the population registered in 2011. The expected further decline in the number of inhabitants will not be linear, and we expect a greater imbalance between certain large (functional) age contingents, especially in the relation: young - old population.

Keywords: Eastern Croatia, demographic development, depopulation, demographic aging.

* Dražen Živić, Ph. D., Institute of Social Sciences Ivo Pilar - Local center Vukovar, J. J. Strossmayera 25, P.O. box 58, 32000 Vukovar, Croatia, drazen.zivic@pilar.hr 